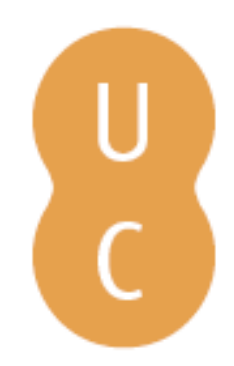

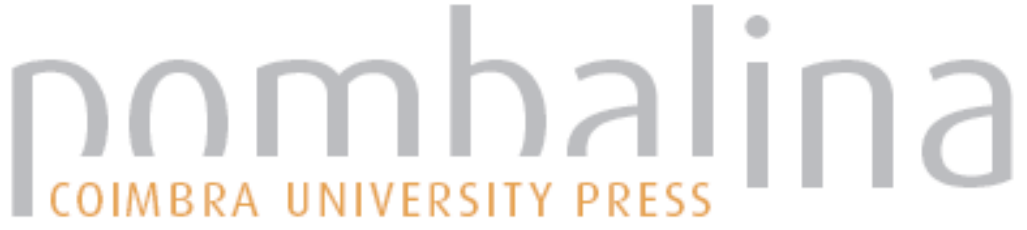

\section{A elegia na lírica de Camões}

Autor(es): $\quad$ Silva, Vítor Aguiar e

Publicado por: Imprensa da Universidade de Coimbra

URL

persistente: $\quad$ URI:http://hdl.handle.net/10316.2/30738

DOI: $\quad$ DOI:http://dx.doi.org/10.14195/978-989-26-0569-2_1

Accessed : $\quad$ 26-Apr-2023 13:53:52

A navegação consulta e descarregamento dos títulos inseridos nas Bibliotecas Digitais UC Digitalis, UC Pombalina e UC Impactum, pressupõem a aceitação plena e sem reservas dos Termos e Condições de Uso destas Bibliotecas Digitais, disponíveis em https://digitalis.uc.pt/pt-pt/termos.

Conforme exposto nos referidos Termos e Condições de Uso, o descarregamento de títulos de acesso restrito requer uma licença válida de autorização devendo o utilizador aceder ao(s) documento(s) a partir de um endereço de IP da instituição detentora da supramencionada licença.

Ao utilizador é apenas permitido o descarregamento para uso pessoal, pelo que o emprego do(s) título(s) descarregado(s) para outro fim, designadamente comercial, carece de autorização do respetivo autor ou editor da obra.

Na medida em que todas as obras da UC Digitalis se encontram protegidas pelo Código do Direito de Autor e Direitos Conexos e demais legislação aplicável, toda a cópia, parcial ou total, deste documento, nos casos em que é legalmente admitida, deverá conter ou fazer-se acompanhar por este aviso.

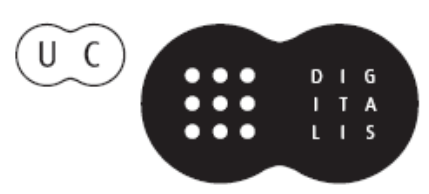




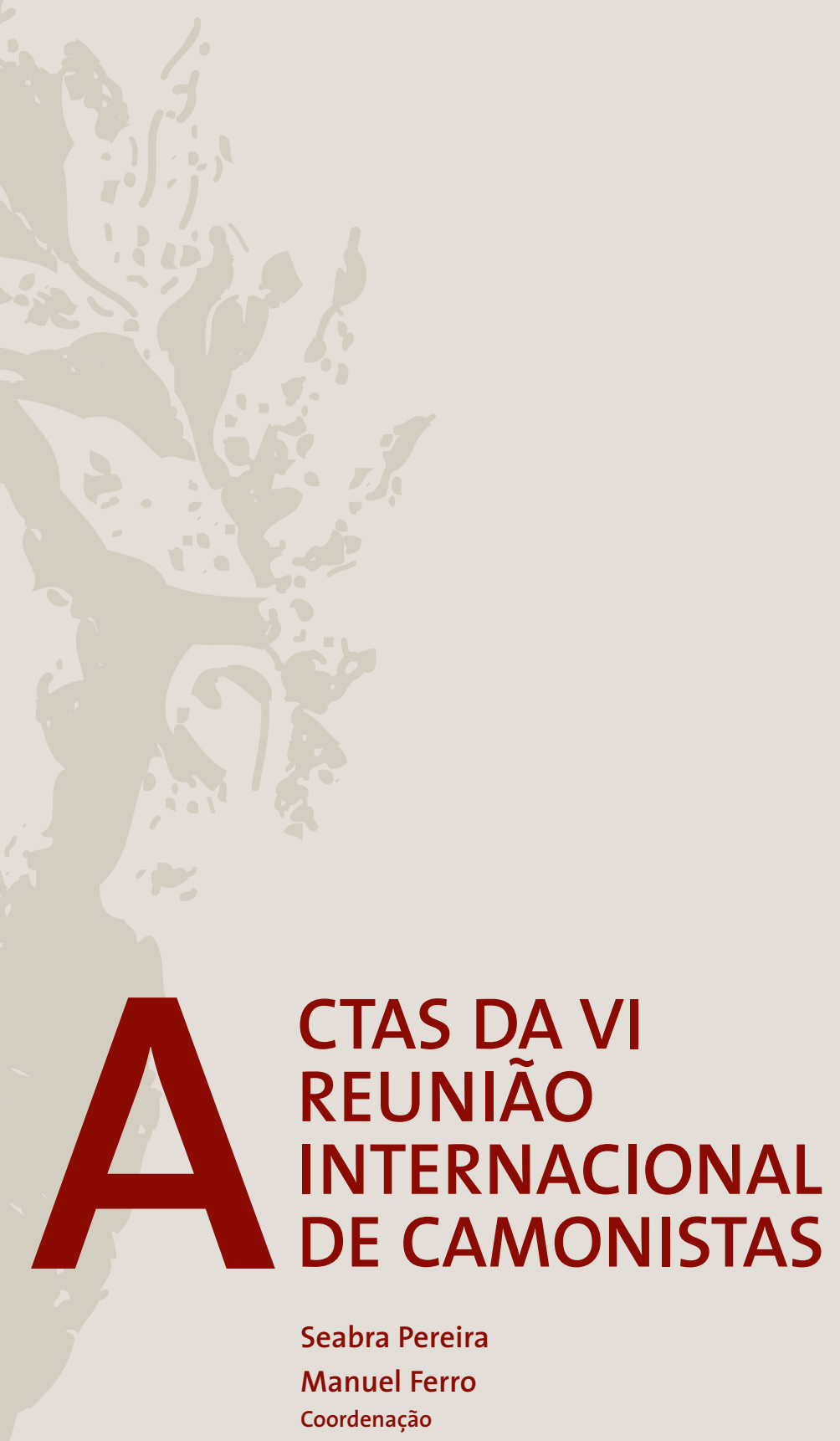


Vítor Aguiar e Silva

Universidade do Minho

\section{A ELEGIA NA LÍRICA DE CAMÓES ${ }^{I}$}

Dezasseis anos atrás, neste mesmo lugar, e no termo de uma reunião científicocultural como a que hoje nos congrega - a III Reuniâo Internacional de Camonistas, realizada de 10 a 13 de Novembro de 1980 -, propus, com outros Colegas, a criação de um Centro Interuniversitário de Estudos Camonianos que, em Portugal e no estrangeiro, especialmente no Brasil, coordenasse, promovesse e difundisse os estudos sobre Luís de Camóes.

Adversidades e acidentes do tempo e da fortuna explicam, mas não justificam, que a concretização de tão relevante projecto tivesse sofrido dificuldades, demoras, atrasos e longas pausas. Nunca deixei de apoiar a criação desse Centro e, num momento institucionalmente decisivo, quando a Junta Nacional de Investigação Científica alterou profundamente a sua política em relação às ciências humanas e sociais, tive a possibilidade de intervir no processo, propondo formalmente ao então Presidente daquele organismo, Prof. Doutor Fernando Ramôa, a sua aprovação. Mais de uma década após a proposta inicial, o projecto alcançava enfim a sua realização.

Este projecto de natureza científica e cultural, pela sua dimensão de memória e pela sua dimensão de futuro, é uma das raízes e um dos horizontes que me ligam a esta alma mater conimbrigensis que é a minha Universidade originária e só a minha quotaparte na sua ideação e na sua efectivação poderá explicar que, perante auditório tão ilustre, seja eu quem profere a conferência inaugural desta Reunião, correspondendo ao generoso convite formulado pelo meu Amigo e Colega, Doutor Aníbal Pinto de Castro.

Na história da poesia ocidental, desde o século VII A.C. até ao século XX, a elegia constitui uma das mais complexas, duradouras e polimórficas manifestaçôes de um modo e de um género literários e por isso mesmo tem suscitado, nos últimos anos,

\footnotetext{
${ }^{1} \mathrm{O}$ texto agora publicado desta conferência inaugural da VI Reunião Internacional de Camonistas apresenta algumas modificaçôes em relação ao texto originário.
} 
um particular interesse aos investigadores da poética histórica, da poética teórica, da história literária e da literatura comparada ${ }^{2}$.

Que, tantos séculos depois de os poetas elegíacos gregos e de os poetas elegíacos latinos terem criado muitos dos poemas formalmente mais refinados e tematicamente mais fascinantes e perturbadores da "poesia antiga", alguns dos mais belos, esplendorosos e comoventes poemas da "poesia moderna", desde Milton a Yeats, Rilke, García Lorca, Auden e Seamus Heaney, passando por André Chénier, Goethe, Hölderlin, Shelley, Wordsworth, Leopardi, Tennyson e Thomas Hardy, sejam elegias, é obrigatório motivo de reflexão, sobretudo no quadro do que se pode designar por antropologia do fenómeno poético. Ao longo de vinte e sete séculos, mudaram-se os esquemas métricos, alteraram-se as formas estróficas e poemáticas, transformaram-se as crenças e convicçôes religiosas e morais, os sistemas sociais e políticos, as ideias e os valores da vida humana, mas o modo elegíaco e o género elegíaco ${ }^{3}$, sob diversas metamorfoses históricas, permaneceram como manifestaçôes cimeiras da poesia ocidental, porque a elegia é a voz e o canto das duas realidades primordiais, constantes e indissociáveis da existência humana: a morte e o amor, o luto e o sofrimento da perda irremediável e o fulgor, o júbilo e as inquietaçóes da vivência do amor.

Os prantos e as lamentaçôes fúnebres abundam em todas as literaturas românicas medievais, tendo como modelo mais próximo o planh provençal e como modelo mais distante o planctus latino-medieval ${ }^{4}$. São expressóes da necessidade antropológica e

\footnotetext{
2 Menciono alguns dos mais importantes estudos sobre a elegia publicados nas duas últimas décadas: Paul Veyne, L'élégie érotique romaine: L'amour, la poésie et l'Occident, Paris, Éditions du Seuil, 1983; R. Whitaker, Myth and personal experience in roman love-elegy. A study in poetic technique, Göttingen, Vandenhoeck \& Ruprecht, 1983; Peter M. Sacks, The english elegy. Studies in the genre from Spenser to Yeats, BaltimoreLondon, The Johns Hopkins University Press, 1985; Celeste Schenck, Mourning and panegyric: The poetics of pastoral ceremony, University Park, Pennsylvania State University Press, 1988; Duncan F. Kennedy, The arts of love. Five studies in the discourse of roman love elegy, Cambridge, Cambridge University Press, 1993; Gian Biagio Conte, Genres and readers. Lucretius, love elegy, Pliny's Encyclopedia, Baltimore-London, The Johns Hopkins University Press, 1994; Jahan Ramazani, The poetry of mourning: The modern elegy from Hardy to Heaney, Chicago, University of Chicago Press, 1994; W. David Shaw, Elegy and paradox. Testing the conventions, Baltimore-London, The Johns Hopkins University Press, 1994; Begoña López Bueno (ed.), La elegía, Universidad de Sevilla-Universidad de Córdoba, 1996; Melissa F. Zeiger, Beyond consolation: Death, sexuality, and the changing shapes of elegy, Ithaca-London, Cornell University Press, 1997.

${ }^{3}$ Modo elegíaco é um conceito hiperonímico em relação a género elegíaco: todas as elegias se inscrevem no modo elegíaco, mas o modo elegíaco desborda os limites da elegia, manifestando-se noutros géneros literários. Sobre esta distinção, cf. Morton W. Bloomfield, "The elegy and the elegiac mode: Praise and alienation”, in Barbara Kiefer Lewalski (ed.) Renaissance genres. Essays on theory, history, and interpretation, Cambridge, Mass.-London, Harvard University Press, 1986, pp. 147-157.

${ }^{4}$ Veja-se o estudo de M. ${ }^{a}$ Emilia García Jiménez, La poesía elegíaca medieval en lengua castellana (Logrońo, Instituto de Estudios Riojanos, 1994), que apresenta uma pormenorizada informação sobre a poesia elegíaca fúnebre na literatura castelhana, com uma adequada perspectiva comparatista. No Cancioneiro geral de Garcia de Resende (1516), figuram diversos poemas que constituem prantos e lamentaçôes. Entre eles, merece destaque a composição de D. João Manuel à morte do príncipe D. Afonso, "em modo de lamen-
} 
afectiva, do imperativo religioso e moral e das convençôes e conveniências sociais de chorar e lamentar a morte de alguém, louvando as suas virtudes, o seu valor e os seus feitos e meditando sobre os mistérios da morte e do além-túmulo. Nalguns casos, como no Planto que fizo la Pantasilea, poema hoje atribuído a Juan Rodríguez del Padrón, o género medieval e trovadoresco do planh combina-se com marcas temáticas e estruturais oriundas da tradição elegíaca classicista, em particular das Heroides de Ovídio 5 .

No De vulgari eloquentia, tratado sobre a língua e a poesia redigido provavelmente entre 1303 e 1305, Dante define a elegia como o estilo dos infelizes: "Per elegiam stilum intelligimus miserorum" ${ }^{6}$. É uma definição que retoma a caracterizaçáo da elegia que se encontra em diversos tratadistas da poética medieval, desde Papias a Uguccione da Pisa, Giovanni da Genova e John Garland, e que assenta numa base temática, embora Dante venha a complementar a sua definição com o nível estilístico baixo ou humilde do género.

Livro de dores, infortúnios e sofrimentos de amor é Il libro chiamato Elegia di Madonna Fiammeta da lei alle innamorate donne mandato de Boccaccio, um livro escrito, como no "Prologo" se diz, com "lagrimevole stilo", por uma mulher "afflitta (...) bagnata delle mie lagrime". Boccaccio reitera assim a caracterização temática da elegia que provinha da Ars poetica de Horácio (a querimonia do v. 76) e das Heroides de Ovídio (XV, 7: elegia flebile carmen), mas abre um horizonte genológico diverso daquele que propunha o De vulgari eloquentia. Por um lado, a Elegia di Madonna Fiammetta, que tem como modelo as Heroides, embora não seja formalmente uma epístola, é um desesperado monólogo do sofrimento amoroso, associando assim a lamentação e o infortúnio de amor; por outro, como Cesare Segre sublinhou, esta elegia nada tem a ver com um nível estilístico baixo e humilde ${ }^{7}$.

No âmbito das literaturas hispânicas, importa recordar que o marquês de Santillana, no seu Prohemio y carta al illustre Señor don Pedro, muy magnifico Condestable de Portugal, datável de 1446 , circunscreve a poesia elegíaca a cantos fúnebres ${ }^{8}$, mas que Juan de Mena, no Laberinto de Fortuna, caracteriza o "elegíaco verso" como "triste canción", como canto desesperado e choroso provocado pelas penas, pelos enganos e erros do amor?.

No século XV, os humanistas italianos redescobriram os grandes poetas elegíacos latinos, Catulo, Tibulo, Propércio e Ovídio. A elegia erótica refloresce numa poesia

taçam”, porque revela, na oitava final, clara consciência das convenções deste género poético: “Qualquiera que sufre tan grave manzilha / no busque manera de ser consolado, / no menos m'escusa aquesta obrezilha, / pues lamentacion sea intitulado" (Cancioneiro geral de Garcia de Resende. Fixação do texto e estudo por Aida Fernanda Dias. Lisboa, Imprensa Nacional-Casa da Moeda, 1990, vol. 1, p. 398).

${ }^{5}$ Cf. Guillermo Serés, "La elegía de Juan Rodríguez del Padrón”, Hispanic review, 62, 1 (1994), pp. 1-22.

${ }^{6}$ Cf. Dante, De vulgari eloquentia, Cambridge, Cambridge University Press, 1996, p. 56 (II, IV, 6).

${ }^{7}$ Cesare Segre, «Strutture e registri nella Fiammetta», Le strutture e il tempo. Narrazione, poesia, modelli, Torino, Einaudi, 1974, pp. 89-90.

${ }^{8}$ Escreve o marquês de Santillana: "En otros tiempos, a las cenizas e defunciones de los muertos, metros elegiacos se cantavan, e aun agora en algunas partes dura, los quales son llamados endechas" (cf. Marqués de Santillana, Prohemios y cartas literarias. Edición preparada por Miguel Garci-Gómez. Madrid, Editora Nacional, 1984, p. 86).

${ }^{9}$ Cf. Juan de Mena, Laberinto de Fortuna y otros poemas. Edición de Carla de Nigris, Barcelona, Crítica, 1994, p. 109. Na copla 123 do Laberinto, Juan de Mena utiliza a forma elegianos. 
neolatina douta e erudita, graças a poetas humanistas como Enea Silvio Piccolomini, Christophoro Landino, Angelo Poliziano, Giovanni Pontano, Iacopo Sannazaro, etc. ${ }^{10}$. A elegia neolatina, se é frequentemente uma elegia erótica, é também uma forma aberta que acolhe temas como a lamentação fúnebre, a exaltação panegírica, a reflexão e a crítica sociais e políticas, o louvor da amizade, a narrativa de viagens e de exílios, etc.

Mais importante, porém, sob o ponto de vista da evoluçáo genológica da elegia nas literaturas em língua vulgar, é a constituição, na obra de diversos poetas italianos do século XV e das primeiras décadas do século XVI, da elegia escrita em terza rima ou terzina incatenata, um esquema métrico criado por Dante na Divina Commedia e utilizado por Petrarca nos Trionfi e por Boccaccio na Caccia de Diana e na Amorosa visione, o qual, sob a sua aparente simplicidade, pode esconder complexos significados teológicos e antropológicos, como demonstrou John Freccero no seu magnífico estudo intitulado "Il significato della terza rima"11. A terza rima foi considerada como um esquema métrico equivalente ao dístico elegíaco e o seu uso na elegia foi consagrado por Sannazaro nos seus poemas Se mai per meraviglia alzando il viso, uma lamentação sobre o corpo crucificado do Redentor; Scorto dal mio pensier fra i sassi e l'onde, sobre a morte do marquês de Pescara; e La notte, che dal ciel, carca d'oblio, à morte de Pier Leone. A estrutura métrica da elegia assim autorizadamente estabelecida por Sannazaro foi corroborada por outros influentes autores de elegias como Bembo, Ariosto, Bernardo Tasso e Luigi Alamanni e tornou-se canónica nas literaturas castelhana e portuguesa do Renascimento e do Maneirismo, embora ocorram excepçóes ${ }^{12}$.

Quando Garcilaso de la Vega, seguindo os modelos renascentistas, escreveu as primeiras elegias "modernas" da literatura castelhana, adoptou a terza rima. O mesmo esquema métrico-formal adoptaram Sá de Miranda, Camóes, António Ferreira e Diogo Bernardes.

Sob o ponto de vista temático, as duas elegias de Garcilaso representam os dois grandes modelos da elegia renascentista (em conformidade, aliás, com a matriz greco-latina do género). A elegia I, endereçada ao duque de Alba por ocasião da morte do irmão deste, D. Bernaldino de Toledo, é uma elegia fúnebre, com o elogio do defunto, a consolação ao destinatário, reflexôes de ordem filosófico-moral sobre a fama e a imortalidade e a visão dos bem-aventurados; a elegia II, endereçada a Boscán, é fundamentalmente uma elegia amorosa, embora com elementos temáticos de crítica à vida da corte.

Tal como acontece com a elegia latina, a elegia do Renascimento e do Maneirismo é um mosaico ou uma poikilía de diversos géneros e subgéneros. A sua contaminatio

${ }^{10}$ Veja-se a bem informada síntese de Juan F. Alcina, "La elegía neolatina”, in Begońa López Bueno (ed.), La elegía, ed. cit., pp. 15-40. Veja-se também a obra de Clifford Endres, Joannes Secundus. The latin love elegy in the Renaissance, Hamden, Conn., Archon Books, 1981.

${ }^{11}$ Estudo incluído no livro de John Freccero, Dante. La poetica della conversione, Bologna, Il Mulino, 1989.

12 Por exemplo, a elegia ¿Como cantaré yo en tierra extraña? de Diego Hurtado de Mendoza, a "Elegia a la muerte de Dońa Maria” com o incipit ;Ay muerte dura ; ay dura y cruda muerte! de Gregorio Silvestre, e três elegias de Andrade Caminha, compostas duas delas em décimas de redondilha maior e uma em oitavas de verso decassilábico: Desque meus olhos não vem; Trago a vida inquieta, Alma cansada; Não deixa Amor entender-se. 
com a epístola e a sátira, que Claudio Guillén analisou num estudo modelar ${ }^{13}$, é a reemergência de uma vocação primigénia da elegia, tornando fluidas e moventes as suas delimitaçóes semântico-pragmáticas. Em contrapartida, com algumas e pouco relevantes excepçóes, o seu esquema métrico é fortemente estável. Ora, como este esquema era também o significante métrico, digamos assim, de outros géneros e subgéneros poéticos - epístola, sátira, etc. ${ }^{14}$ - e como o termo capitulo significou primeiramente uma série de tercetos rematada com um verso isolado que rimava com o penúltimo verso do último terceto, aquele termo passou a designar todas as composiçôes escritas em terza rima, independentemente da sua forma de conteúdo e da sua inserção genológica.

Esta extensão do termo capítulo, utilizado como hiperónimo de termos como elegia, epistola, sátira, etc., justifica-se pela estabilidade da forma de expressão e pela inversa variabilidade das formas de conteúdo. Embora com uma relevante alteração terminológica, é este tipo de justificação que conduz Faria e Sousa, na abertura dos seus comentários ao tomo IV, parte II, das Rimas varias de Luis de Camoens, a decidir chamar elegias a todos os poemas que Camóes escreveu em tercetos. Explica assim as razóes da sua decisão: "Elegia se puede llamar qualquier Poema de assunto triste: pero ya está introduzido que las Elegias se han de escrivir más en Tercetos que en otro genero alguno de composicion: y en esta se escriven tambien materias que no solo no son tristes, mas aun alegres, amorosas, laudatorias, cartas y satiras: y por esto llamo Elegias a todos los Poemas que mi Maestro escriviò en Tercetos; y tambien porque como fue necesario citarlos en muchos lugares, podia hazer alguna confusión el usar de más de um nombre, pudiéndoseles dar diferentes, conforme á sus argumentos, que (como dellos se verá) son varios" ${ }^{15}$. Em vez do hiperónimo capitulo, Faria e Sousa adopta o hiperónimo elegia, mas procede necessariamente à sua neutralização semântico-pragmática, isto é, deixa de considerar como relevantes e pertinentes a sua diversidade de argumentos, atendendo-se tão-só à permanência do esquema métrico.

13 Cf. Claudio Guillén, "Sátira y poética en Gracilazo”, El primer siglo de oro. Estudios sobre géneros y modelos, Barcelona, Editorial Crítica, 1988, pp. 15-48. Na poesia e nas poéticas francesas do século XVI, a contaminatio entre a elegia e a epístola, em grande parte originada pelo modelo das Heroides de Ovídio, é generalizada (veja-se Christine M. Scollen, The birth of the elegy in France 1500-1550, Genève, Droz, 1967, pp. 13 ss).

${ }^{14}$ A terza rima com rimas esdrúxulas aparece, por exemplo, em églogas da Arcadia de Sannazaro. Herrera, nos seus comentários a Garcilaso, sublinhou a multiforme capacidade genológica da terza rima: "Aunque nos sirve mucho este género de metro para escribir elegías y cosas amatorias y epístolas y sátiras, y es muy acomodado para tratar historia” (cf. Antonio Gallego Morell (ed.), Garcilaso de la Vega y sus comentaristas, Madrid, Editorial Gredos, ${ }^{2} 1972$, p. 423). As anotaçōes de Herrera foram publicadas na sua edição das obras de Garcilaso, dada à luz em 1580. No mesmo ano, Miguel Sánchez de Lima publicou El arte poético en romance castellano, obra em que sobre a terza rima expendeu consideraçôes idênticas às de Herrera (cf. a ediçấo da arte poética de Sánchez de Lima preparada por Rafael Balbín Lucas, Madrid, CSIC, 1944, p. 60). Poderá ter havido influência de Sánchez de Lima sobre Herrera - El arte poético tem as licenças datadas de 1576 -, mas o mais provável é que ambos tenham bebido numa fonte comum, como leva a concluir o estudo de Bienvenido Morros, "Las fuentes y su uso en las Anotaciones a Garcilaso", Begońa López Bueno (ed.), Las “Anotaciones” de Fernando de Herrera. Doce estudios, Universidad de Sevilla, 1997, p. 71.

${ }^{15}$ Cf. Rimas varias de Luis de Camoens, Lisboa, en la Imprenta Craesbeeckiana, 1689, tomo IV, parte II, p. 1. 
Falar da poesia elegíaca de Camóes obriga a falar - como acontece, aliás, em relação a todos os outros géneros, subgéneros e formas poéticas fixas das Rimas - do cânone das elegias de Camóes.

$\mathrm{Na}$ editio princeps das Rhythmas (1595), a terceira parte é constituída pelas elegias e por algumas oitavas, sendo nela publicadas três elegias: O poeta Simónides falando, Aquela que de amor descomedido e O sulmonense Ovídio desterrado (esta, por lapso, traz a menção de "Elegia segunda", quando devia ser a "Elegia terceira"). Entre estas três elegias, sobre cuja autenticidade autoral não paira qualquer dúvida, e as oitavas "A Dom António de Noronha, sobre o desconcerto do mundo", encontra-se a composição Aquele mover d'olhos excelente, classificada como capitulo. A edição de 1598 emendou o erro de ordenação relativo à elegia $O$ sulmonense Ovídio desterrado e intercalou entre as três citadas elegias e o capítulo Aquele mover d'olhos excelente os tercetos "A Dom Lionis Pereira, sobre o liuro que Pero de Magalhães lhe offereceo do descubrimento da terra Sancta Cruz", já publicados em 1576 na História da Província de Santa Cruz de Pero de Magalhães Gândavo.

Em rigor, por conseguinte, quer o responsável pela organização da editio princeps das Rhythmas - muito provavelmente Fernão Rodrigues Lobo Soropita -, quer Estêvão Lopes, o responsável pela edição de 1598, só classificam como elegias três poemas, sendo muito discutível o critério dos editores modernos e contemporâneos que classificam como elegias aquele capítulo e aqueles tercetos, com base, afinal de contas, num conceito meramente métrico de elegia, na esteira de Faria e Sousa. Os tercetos endereçados a Dom Leonis Pereira são um poema laudatório, com importantes reflexóes sobre as letras e as armas, não apresentando quaisquer elementos de ordem semântica - pertencentes ao "argumento", como diz Faria e Sousa - que justifiquem a sua classificação como elegia. O capítulo Aquele mover d'olhos excelente, que Faria e Sousa declara colocar "debaxo del título de las Elegias por no hazer tantos títulos", é um poema petrarquista sobre a fenomenologia do enamoramento e sobre o tormento e a glória de ser vencido por tấo "linda Dama", não sendo uma elegia fúnebre, nem, em rigor, uma elegia amorosa.

Domingos Fernandes, na edição das Rimas de 1616, integrou no corpus da lírica camoniana uma elegia autêntica, Se quando contemplamos as secretas, atribuída a Camóes no "Índice" do Cancioneiro do P. Pedro Ribeiro e no manuscrito 12-26-8/D-199 da Real Academia de la Historia de Madrid, mas incluiu nele igualmente duas elegias apócrifas (Duvidosas esperanças, certo medo e Se obrigaçóes de fama podem tanto).

Álvares da Cunha, na Terceira Parte das Rimas do Princepe dos Poetas Portugueses Luis de Camões, editada em 1668, atribuiu a Camóes mais nove elegias, das quais apenas uma, Que novas tristes são, que novo dano!, encontrou acolhimento nas edições de José Maria Rodrigues e Afonso Lopes Vieira, Hernâni Cidade e Costa Pimpão, embora Cidade, na esteira de dúvidas formuladas por Storck e Carolina Michaëlis de Vasconcelos, tenha publicado o poema com algumas reservas.

Na sua edição das Rimas, na segunda parte, tomo IV, publicada em 1689, Faria e Sousa incluiu na lírica camoniana mais cinco elegias, que têm sido e devem continuar a ser consideradas como apócrifas. Em relação a uma delas, Belisa único bem desta 
alma triste, o próprio Faria e Sousa confessa que num dos manuscritos por si utilizados o poema se encontrava atribuído a Francisco de Andrade (autoria confirmada pelo Cancioneiro de Luis Franco Correia, fl. 221 r. e pelo ms. 8920, fl. 394 v., da Biblioteca Nacional de Lisboa).

Finalmente, o visconde de Juromenha integrou no corpus da lírica camoniana mais sete elegias, das quais apenas uma, Divino, almo Pastor, Délio dourado, foi aceite como autêntica por José Maria Rodrigues e Afonso Lopes Vieira, por Hernâni Cidade e por Maria de Lurdes Saraiva e publicada em apêndice por Costa Pimpáo, com a seguinte cautelosa e dubitativa nota explicativa: "Embora, de acordo com Storck, tenhamos dúvidas sobre a autoria camoniana desta Elegia, inserimo-la neste lugar, com o soneto que se lhe segue no manuscrito de Luís Franco, porque, dada a importância do poema, não nos atreveríamos a correr o risco da sua supressão, pura e simples" 16 .

O corpus das elegias que considero canónicas coincide com o proposto por Costa Pimpão, mas não classificando como elegias o capítulo Aquele mover d'olhos excelente e os tercetos endereçados a Dom Leonis Pereira e não perfilhando em relação à elegia Divino, almo Pastor, Délio dourado a atitude benevolentemente dubitativa do saudoso Mestre. Com efeito, trata-se de uma composição poética que no Cancioneiro de Luís Franco Correia não tem atribuição de autoria, que não ocorre em nenhum outro manuscrito e que o visconde de Juromenha abusivamente integrou, como fez com tantos outros poemas, na lírica de Camóes. Apesar de algumas afinidades estilísticas, formais e semânticas com outros textos de Camóes - afinidades que o P. e Abel Guerra diligentemente coligiu em estudo publicado em $1980^{17}$-, ocorrem no soneto posposto à elegia naquele cancioneiro alguns casos de hapax legomenon - cibam, poção, infusas - que suscitam muitas dúvidas quanto à autenticidade camoniana deste texto e, sobretudo, encontra-se no mesmo soneto uma exaltaçáo da poesia ao divino, com a consequente condenaçáo da poesia profana, que tenho grande dificuldade em aceitar como representativa da poética e da poesia camonianas. Existe em Camóes poesia religiosa, poesia de profundas raízes religiosas, poesia agonicamente religiosa, mas não poesia ao divino em sentido estrito.

O modo elegíaco, na lírica camoniana, extravasa, porém, dos limites do corpus das elegias assim configurado. Manifesta-se, por exemplo, em sonetos como Em flor vos arrancou, de então crecida, consagrado à morte de D. António de Noronha, Esforço grande, igual ao pensamento, dedicado à memória de D. Henrique de Meneses, ou Chorai, Ninfas, os fados poderosos, homenagem funérea a uma formosa mulher arrebatada pela morte, e perpassa sobretudo na sua poesia bucólica, merecendo particular destaque

16 Luís de Camões, Rimas. Texto estabelecido, revisto e prefaciado por Álvaro J. da Costa Pimpão. Apresentação de Aníbal Pinto de Castro. Coimbra, Livraria Almedina, 1994, p. 385. As citações adiante feitas da lírica camoniana procedem desta edição.

17 Cf. Abel Guerra, "Será realmente de Camões a elegia Divino, almo pastor...?", in Brotéria, 110, 7/8 (1980), pp. 183-200. Leodegário Amarante de Azevedo Filho afirma que, no Cancioneiro de Luís Franco Correia, a elegia está atribuída a Francisco Mendonça (cf. Lírica de Camóes. 4. Tomo I. Elegias em tercetos, Lisboa, Imprensa Nacional-Casa da Moeda, 1998, p. 49). Não é verdade, pois que a epígrafe do poema reza assim: "Elegia de sesta fra dendoenças". 
a égloga I, Que grande variedade vão fazendo, consagrada à morte de D. António de Noronha e à morte do príncipe D. João, pai do futuro rei D. Sebastiâo ${ }^{18}$.

As três elegias, assim explicitamente classificadas, publicadas logo na editio princeps das Rhythmas - O poeta Simónides, falando, Aquela que de amor descomedido e $O$ sulmonense Ovidio desterrado -, constituem, segundo o meu juízo, a parte esteticamente mais valiosa da poesia elegíaca de Camóes e por isso mesmo - e também pelas constriçóes temporais que a todos nos obrigam - irei ater-me à sua análise.

A elegia $O$ poeta Simónides, falando é um poema com uma estrutura formal e semântica complexa. Os primeiros sessenta versos constituem uma dramática reflexão poético-filosófica sobre a memória e as artes da memória, temas profundamente ligados à semântica do género elegíaco como canto melancólico sobre a perda da coisa amada. A segunda metade desta primeira parte, com início no verso 28, representa o que Francesco Robortello designa por oraçóes ou frases patéticas da elegia ${ }^{19}$, isto é, um tipo de discurso adequado ao desafogo emotivo do poeta e apto a comover o ânimo dos leitores. $\mathrm{O}$ eu lírico, após o segmento inicial de natureza narrativa, com recurso inclusive ao diálogo, apodera-se de modo veemente da cena da enunciação, adoptando o modo enunciativo exegemático para exprimir as suas queixas e dolorosas confissões, mas acumulando também as interrogaçóes que convocam e interpelam dramaticamente um auditório ante o qual o poeta exibe, em hipérboles narcisistas, os sofrimentos e as misérias da sua vida:

"De que serve às pessoas alembrar-se

Do que passou já, pois tudo passa,

Senão de entristecer-se e magoar-se?

Porque me não criara a minha estrela

Selvático no mundo, e habitante

$\mathrm{Na}$ dura Cítia, ou na aspereza dela?

Ou no Cáucaso horrendo, fraco infante,

Criado ao peito d'algúa tigre Hircana,

Homem fora formado de diamante;

Porque a cerviz ferina e inumana

Náo sometera ao jugo e dura lei

Daquele que dá vida quando engana”.

${ }^{18}$ A contaminatio entre a elegia e a bucólica manifesta-se já na poesia helenística, como demonstram o idílio I de Teócrito, o famoso canto fúnebre por Adónis de Bíon e o canto fúnebre por Bíon do pseudo-Mosco. A V e a $\mathrm{X}$ Bucólicas de Virgílio prolongam e canonizam, digamos assim, esta contaminatio, que vai reaparecer em poetas renascentistas como Sannazaro e Garcilaso. Veja-se Ellen Lambert, Placing sorrow: A study of the pastoral elegy from Theocritus to Milton, Chapel Hill, University of North Carolina Press, 1976; Juan Montero, "Sobre las relaciones entre la elegía y la égloga en la poesía del siglo XVI”, in Begońa López Bueno (ed.), La elegía, pp. 215-225.

${ }^{19}$ Cf. Francesco Robortello, Explicationes de satyra, de epigrammate, de comedia, de elegia [1548], in Bernard Weinberg (a cura di), Trattati di poetica e retorica del Cinquecento, Bari, Laterza, 1970, vol. I, p. 535. 
O verso 61 e seguintes revelam que esta elegia é também uma epístola. Aliás, a epígrafe que acompanha a transcrição do poema no Cancioneiro de Luís Franco Correia (fl.4 r) torna explícita a forma epistolográfica da elegia: "Elegia $3^{a}$ da India a dom Anto de Noronha”. O leitor menos atento ou apressado poderá não se dar conta desta contaminatio genológica, já que a forma de endereçamento ao destinatário não se encontra colocada no seu lugar canónico, que é o início do poema. Como Faria e Sousa pertinentemente observou, o destinatário inominado desta elegia deveria ser alguém que mantinha relações de grande confiança pessoal com Camóes, já que as formas verbais de tratamento não traduzem uma respeitosa relação de cortesia (a informação proporcionada pelo Cancioneiro de Luís Franco Correia sobre o destinatário da elegia poderia corroborar a justeza da observação de Faria e Sousa, como este próprio anotou, ao referir-se à grande amizade existente entre D. António de Noronha e Camóes, se não fora a diferença em relação às formas verbais cerimoniosas da dedicatória da "Égloga dos Faunos", que a edição princeps das Rhythmas (1595) apresenta na epígrafe como tendo sido "dirigida a dom Antonio de Noronha"). Merece realce o modo como o poeta, dirigindo-se ao seu destinatário, caracteriza o texto da sua elegia epistolar: "longa e mísera escritura." Misera escritura é um sintagma bem apropriado à semântica do género elegíaco: escrita de dores, de sofrimento e desgraças.

Após os dois tercetos que contêm a fórmula de endereçamento epistolar, iniciase com o verso 76 o excurso narrativo que, com excepção de algumas cogitaçóes, rememoraçóes, apóstrofes e exclamaçóes patéticas, ocupa a parte restante do poema. Este excurso narrativo, no qual se relata a viagem marítima do poeta para a Índia, se descreve a tempestade formidanda que assolou as naus depois da passagem pelo Cabo da Boa Esperança e se conta a expedição bélica contra o rei de Chembe, efectuada em fins de 1553, confere à elegia as características do que Robortello denominou a oratio morata requerida pela elegia, isto é, o discurso apropriado a descrever os costumes dos homens ou, segundo a explicação de Cascales, a frase "que comprehende y descubre las costumbres del hombre, guardando las circunstancias de las cosas, de los ofícios, del lugar, del tiempo y de todo aquello que llamamos ley del decoro" 20 .

As circunstâncias de tempo e de lugar, as circunstâncias das coisas e das acçôes articulam-se, porém, de modo profundamente coerente com as "oraçóes patéticas" da elegia, visto que o apartamento da pátria, a viagem marítima, os perigos do mar e da guerra, a errância por longínquas paragens configuram o quadro existencial adequado à expressão das lembranças e mágoas de amor e dos anseios por uma vida rústica, serena e tranquila.

Deve ser sublinhada a apóstrofe dirigida às claras Ninfas marinhas com que o poeta interrompe o seu excurso narrativo. Ainda mal iniciada a viagem, o poeta fixa os olhos rasos de água nas ondas do oceano, sem nada ver do mundo exterior, porque só as lembranças lhe ocupam o espírito, como diz neste belíssimo terceto, com uma audaciosa metáfora inicial e com uma subsequente estrutura quiasmática fortemente expressiva:

${ }^{20}$ Cf. Antonio García Berrio, Introducción a la poética clasicista. Comentario a las "Tablas Poéticas" de Cascales, Madrid, Taurus, 1988, pp. 267-268. 
"Eu, trazendo lembranças por antolhos,

Trazia os olhos na água sossegada,

E a água sem sossego nos meus olhos.”

Toldados assim os olhos de lágrimas sem sossego, abismado na memória do seu amor desgraçado, o poeta implora às ninfas, num sussurro de quem não quer "mostrar [seu] mal a toda a gente", que se forem, alguma vez, à foz do Tejo, deixem nas "tágicas areias" testemunho do seu amor e do seu tormento:

"Nelas em verso erótico e elegante,

Escrevei cúa concha o que em mim vistes:

Pode ser que algum peito se quebrante."

Aceito a emendatio que Faria e Sousa propôs, invocando a lição de um manuscrito por si utilizado, para o primeiro verso do terceto (emendatio também aceite por Hernâni Cidade). Com efeito, a lição das ediçôes de 1595 e 1598 - "verso heróico e elegante" - é incongruente e terá resultado de erro de copistas, editores ou tipógrafos (fica afastada a hipótese de uma intervenção censória, visto que esta mesma lição figura no Cancioneiro de Luis Franco Correia). O sintagma camoniano tem claramente um significado modal, genológico e estilístico e não um significado tecnicamente métrico, como propóem aqueles comentaristas que entendem por "verso heróico" o verso decassilábico com acentuação nas sexta e décima sílabas. Ora, na tradição elegíaca latina, que Camóes conhecia bem, o modo e o género épicos, ou seja heróicos, eram considerados como géneros elevados, tanto na forma do conteúdo como na forma da expressão, ao passo que o género elegíaco, na esteira de uma tradição que procedia de Calímaco, era valorado como um género "leve", sem a ambição e a gravidade estilístico-formais e semânticas do modo e do género épicos. No contexto da elegia camoniana, a expressão "verso heróico", nesta perspectiva, carece de sentido, ao passo que o sintagma "verso erótico e elegante" exprime admiravelmente a outra face da semântica e do estilo elegíacos que Camóes antes caracterizara como mísera escritura: se a elegia é uma escrita de dores, lamentos e lutos, ela é também escrita erótica, isto é, escrita de amor, escrita do desejo e da saudade amorosa, com o refinamento e a elegância estilístico-formais de que tinham sido mestres inexcedíveis os grandes elegíacos latinos.

A elegia II, Aquela que de amor descomedido, é também uma elegia epistolar, endereçada segundo a editio princeps a D. António de Noronha ${ }^{21}$. À semelhança da elegia

${ }^{21} \mathrm{Na}$ edição das Rhythmas de 1595, a elegia está endereçada a "Dom Antonio de Noronha estando na India”. Na edição de 1598 o endereçamento desapareceu, decerto porque o editor reconheceu que esta informação levantava problemas. Faria e Sousa, leitor atento, observou que esta epígrafe era na verdade ambígua, porque não ficava claro se estava na Índia o poeta ou D. António de Noronha, tornando-se todavia manifesto na elegia que o poeta se encontrava em Ceuta. Costa Pimpão, aceitando a pertinência da observação de Faria e Sousa, emendou assim a epígrafe: "A D. Antonio de Noronha, estando o autor 
I, a fórmula de endereçamento epistolar não figura nos versos iniciais, sendo antecedida por uma curta reflexão sobre o canto poético e o sofrimento amoroso. Tal como a ninfa Eco, perdida pelo seu descomedido amor a Narciso, após ter sido convertida em pedra, apenas conservou de humano a capacidade de repetir os últimos sons das palavras, assim o poeta, prisioneiro do seu sofrimento amoroso, consegue que o seu mal tão-só lhe consinta isto: este canto que escrevo derradeiro. Canto de cisne agónico, canto elegíaco que é identificado como o canto da perda do bem de estar presente, isto é, canto da dor de ausência, canto de melancolia extrema pela perda da presença da mulher amada, canto, por isso mesmo, que o poeta em rigor não escreve, mas que a saudade escreve na sua alma triste e saudosa e que o poeta traslada. A génese da escrita elegíaca é o sentimento destrutivo da perda de um bem essencial e o trabalho de luto que se segue a essa perda e que o poeta exprimiu neste terceto:

"Ando gastando a vida trabalhosa, Espalhando a contínua saüdade Ao longo de úa praia saüdosa".

O sofrimento lutuoso, porém, não é mitigado ou suavizado pela errância incessante à beira-mar. $\mathrm{O}$ oceano, na sua impetuosidade, entra retumbando pelas concavidades da costa e penetra, com a "sua branca escuma furioso", o ventre, o lugar cavernoso da terra:

"Ela, como mais fraca, lhe está dando

As côncavas entranhas, onde esteja

Suas salgadas ondas espalhando."

Numa prosopopeia e em metáforas audaciosas e admiráveis, o poeta sexualiza o mar e a terra e essa visão erótica de um mar impetuoso que derrama as suas salgadas ondas nas entranhas da terra, fúlgida jóia desta elegia, fascina e perturba a sua imaginação e o seu desejo de voyeur, intensificando o seu sofrimento:

"A todas estas cousas tenho enveja

Tamanha, que não sei determinar-me,

Por mais determinado que me veja."

Nem a novidade das paisagens africanas - a elegia, como diz a voz enunciadora, foi escrita em Ceuta -, nem as mudanças das estaçōes, nem a alegria primaveril dos montes, dos rios e das aves, logram consolar a sua melancolia e o seu luto.

A parte final da elegia é um canto de agonia desesperada e, ao mesmo tempo, de fé inquebrantável na eternidade do amor - um amor que nem as sombras frias da

em Ceuta”. Hernâni Cidade, seguindo as conclusōes de estudos de Teófilo Braga e de Carolina Michaëlis, alterou a epígrafe do seguinte modo: «A D. Antấo de Noronha, estando o autor em África» (a nota de Hernâni Cidade a esta epígrafe tem lapsos graves). O Cancioneiro de Luís Franco Correia apresenta a seguinte epígrafe: "Elegia de Ceita a hú seu Amigo". 
morte, nem as negras águas do Cocito, nem os hórridos penedos do inferno poderão obliterar ou extinguir.

$\mathrm{Na}$ sua imaginada catábase ao reino escuro dos mortos e dos condenados por crimes e culpas de amor, o poeta, "com a trémula voz, cansada e fria", celebrará "o gesto claro e puro" da amada perdida, acompanhado pela música de um Orfeu que, desenganado, já sabe que não salvará Eurídice. Verdadeira acmé desta elegia, a catábase infernal do poeta morto irá reacender as memórias de amor das "namoradas sombras", cujo choro vai engrossar as águas do negro rio. O canto de amor volve-se assim num canto órfico que, mesmo sabendo que já não será possível recuperar a coisa amada - Eurídice é o símbolo mitológico dessa perda irremediável -, triunfa sobre o esquecimento e a informe escuridão da morte:

"Que se amor não se perde em vida ausente,

Menos se perderá por morte escura;

Porque, enfim, a alma vive eternamente,

E amor é afeito d' alma, e sempre dura."

A elegia III, O sulmonense Ovidio, desterrado, é por excelência a elegia das amarguras, das privaçóes e dos sofrimentos do desterro, emblematicamente representados pelo poeta latino de Sulmona, condenado como relegatus a viver os últimos anos da sua vida na solidão e na aspereza do Ponto, nos confins orientais do império romano ${ }^{22}$.

Esta elegia, diferentemente das duas anteriores, não tem contaminatio com o género epistolar. É um canto patheticus associado a um canto moratus, pois que o canto de lamento e dor apropriado para despertar a compaixão dos leitores se mescla com um canto em que se evocam e descrevem circunstâncias de tempo e de lugar.

$\mathrm{Na}$ terra do desterro, "quando a roxa manhã, fermosa e bela, / abre as portas ao Sol e cai o orvalho, / e torna a seus queixumes filomela”, o poeta, acordado fisicamente e desacordado psiquicamente, inicia "com passo carregado" - o passo típico do homem melancólico - a sua subida a um outeiro onde se assenta, "soltando a rédea toda a [seu] cuidado". A paisagem das terras circundantes - terras do desterro - é uma paisagem árida e estéril, como na canção IX. O rio Tejo, porém, que se avista do outeiro, neste excurso moratus da elegia, é um rio puro, suave e brando. Nas suas águas, nadam côncavas barcas, símbolos eróticos, símbolos de desejo e da liberdade de que o poeta não pode fruir:

22 O exílio e o desterro, nas suas diversas modalidades, são indissociáveis da poesia elegíaca. Sobre a temática do exílio na poesia do Humanismo português, veja-se a obra de Carlos Ascenso André, Mal de ausência. O canto do exilio na lírica do humanismo português, Coimbra, Minerva, 1992. Sobre as relaçóes da literatura e do exílio, escreveu Claudio Guillén um formoso ensaio: El sol de los desterrados: Literatura y exilio, Barcelona, Quaderns Crema, 1985 (republicado no volume de Claudio Guillén intitulado Múltiples moradas. Ensayo de literatura comparada, Barcelona, Tusquets Editores, 1998). 
"Vejo o puro, suave e brando Tejo,

Com as côncavas barcas, que, nadando,

Vão pondo em doce efeito seu desejo.

Úas co brando vento navegando,

Outras cos leves remos, brandamente,

As cristalinas águas apartando”.

Com as suas aliteraçôes e reiteraçóes vocabulares, o próprio corpo do poema figura o manso e fúlgido caminho da água fluvial que contrasta com a dureza e aridez da terra do desterro. As "côncavas barcas" são femininas barcas do desejo nadando nas águas desse rio que vai deslizando para onde o poeta desejaria partir também. Noutra belíssima prosopopeia, com a alma soltando-se em lágrimas desfeita, o poeta exclama:

"Ó fugitivas ondas, esperai!

Que, pois me náo levais em companhia,

Ao menos estas lágrimas levai,

Até que venha aquele alegre dia

Que eu vá onde vós is, contente e ledo.

Mas tanto tempo quem o passaria?"

O poeta sabe como é ilusória e vã essa esperança de ver chegar ao fim o seu desterro. Como o sulmonense Ovídio, que confessa terem sido causa da sua desgraça um pequeno livro e um error, também Camóes se refere ao "seu erro", mas sublinhando "quão pouca" é a sua culpa. Em conformidade com o modelo argumentativo de algumas elegias de Tristia, Camóes explica que, quando se sofre uma pena com justa causa, a própria consciência da causa como que tira o sentimento da pena. Mas a pena imerecida, como no seu caso, intensifica dramaticamente o sofrimento. Onde começa a realidade autobiográfica e onde acaba o palimpsesto ovidiano?

O final desta elegia repete, no teatro da imaginação, a catábase infernal com que conclui a elegia II, embora sem a riqueza simbólica e a emoção patética deste poema. $\mathrm{O}$ significado desta descida ao inferno, porém, é semelhante ao daqueloutra: a afirmação da perenidade do amor e das memórias amorosas, pois que, contra as forças da imaginação - "a vida / de imaginaçôes tristes se sustenta" -, isto é, contra a capacidade de sonhar do homem, não há portas tartáreas ou águas leteias que prevaleçam.

Canto de amor, canto de desejo, canto de melancolia e de luto, canto fúnebre, canto de saudade e canto de desterro, canto órfico sem Eurídice para resgatar, a elegia é uma das mais pungentes e conturbadas confissões poéticas - confissóes poéticas, reitero e sublinho - da lírica camoniana. Sem consolos ou lenitivos, o canto elegíaco de Camóes confronta impiedosamente o homem com os fantasmas do amor e da morte, com os phantasmata de que se tece a vida do homem melancólico e saturniano, com o vazio ôntico que o próprio canto órfico, tragicamente celebrando a perenidade do amor, não pode exorcismar. Eurídice é o nome dessa perda e desse vazio essenciais. 